\title{
MCF-7 İnsan Meme Kanseri Hücre Soyunda Doksorubisin Öncesi ve Sonrası GST İzozimlerinin, İlaç Dirençlilik Proteinlerinin ve Apoptotik Etkisinin Araştırılması*
}

\author{
Arzu KAYA KOÇDOĞAN***, Serpil OĞUZTÜZÜN ${ }^{* * *}$, \\ Gülçin GÜLER ŞIMMŞEK ${ }^{* * * *}$, Mustafa TÜRK ${ }^{* * * *}$
}

\section{Öz}

Amaç: Kanser hastalığının tedavisinde karşılaşılan klinik sorunlardan biri hastalara uygulanan kemoterapiye karşı tümör hücrelerinin geliştirdiği dirençtir. Tümör hücrelerinin ilaçlara karşı gösterdiği direncin asıl kaynaklarından biri, ilaçların hücre dışına atılmasını sağlayan membran proteinlerinin en önemli üyelerinden ABC (ATP-binding cassette) taşıyıcı proteinleridir. İlaç dirençlilik proteinlerinin yanında diğer hücre içi proteinlerinde etkin olabileceği bilinmektedir. $\mathrm{Bu}$ bağlamda, alkilleyici özellikteki kanser ilaçlarına gelişen dirençte, hücre içi glutatyon ve glutatyon S- konjugatlarının seviyelerinin artmasının rolünün olduğu bildirilmiştir. $\mathrm{Bu}$ çalışmada, Michigan Cancer Foundation-7 (MCF-7) meme kanseri hücre hattında Glutatyon Stransferaz (GST) izozimlerinin çoklu ilaç direnç mekanizmasındaki bazı önemli proteinlerin doksorubisin uygulamasıyla ilişkilerinin incelenmesi amaçlanmıştır.

\footnotetext{
Özgün Araştırma Makalesi (Original Research Article)

Geliş / Received: 17.12.2019 \& Kabul / Accepted: 06.01.2020

* "Bu çalışma, Kırıkkale Üniversitesi, Bilimsel Araştırma Projeleri Koordinasyon Birimi tarafından desteklenmiştir. Proje nümarası: 2015/125"

${ }^{* * *}$ Dr. Öğr. Üyesi, İstanbul Gelişim Üniversitesi, Sağlık Hizmetleri Meslek Yüksekokulu, Patoloji

Laboratuvar Teknikleri, İstanbul, Türkiye, E-posta: akocdogan@gelisim.edu.tr

ORCIID IID https://orcid.org/o0oo-0002-3689-3061

*** Prof. Dr., Kırıkkale Üniversitesi, Fen Edebiyat Fakültesi, Biyoloji Anabilim Dalı, Kırıkkale, Türkiye, E-posta: soguztuzun@yahoo.com ORCID ID https://orcid.org/o0oo-0002-58923735

*****. Doç. Dr., Sağllk Bilimleri Üniversitesi, Ankara Keçiören Eğitim ve Araştırma Hastanesi, Patoloji Ana Bilim Dalı, Ankara, Türkiye, E-posta: drgulcinguler@gmail.com ORCID ID https://orcid.org/o0o0-0001-7710-4631

****** Prof. Dr., Kırıkkale Üniversitesi, Mühendislik Fakültesi, Biyomühendislik Anabilim Dalı, Kurıkkale, Türkiye, E-posta: mtrk.35@gmail.com ORCID ID https://orcid.org/o00o-00018202-090X
} 
Yöntem: Bu çalışmada ilaç uygulanmış ve uygulanmamış meme kanserli MCF-7 hücre hattında GST enzim ailesi ve ABC taşıyıcı proteinlerin ekspresyon ifadeleri immünositokimya yöntemiyle incelenmiştir.

Bulgular: Bu çalışmada, ilaç uygulanmış hücre hatlarında GSTP1, GSTT1, GSTM1, GSTA1, GSTO1, GSTZ1 ve GSTK1 protein ifadelerinin ilaç uygulanmamış hücrelere oranla daha yüksek olduğu görülmüştür; GSTS1 proteini kontrol ve deney gruplarının ikisinde de tespit edilememiştir. İlaç uygulanmış MCF-7 hücre hattında MRP (Multidrug resistance-associated) 2,3,6,7 protein ifadelerinin ilaç uygulanmamış hücrelere oranla daha fazla olduğu görülmüştür. MDR1 (multidrug resistance protein) ve MRP1 proteinleri izlenememiştir. İlaç uygulanmış meme kanserli MCF-7 hücre hattında Bcl-2, p53, p38, caspase-3 protein ifadelerinin ilaç uygulanmamış hücrelere oranla daha fazla olduğu görülmüştür.

Sonuç: ABC süper ailesi üyelerinden MRP 2,3,6 ve 7 ile Faz II enzimleri arasında bulunan GSTP1, GSTT1, GSTM1, GSTA1, GSTO1, GSTZ1 ve GSTK1 izozimlerinin, MCF-7 kanser hücre hattında doksorubisine karşı oluşan ilaç dirençliliğinde rolleri olduğu belirlenmiştir.

Anahtar Kelimeler: Meme kanseri, GST, MDR, MRP, immunositokimya.

\title{
Investigation of GST Isoenzymes, Multi-Drug Resistance Proteins and Apoptotic Effect in MCF-7 Human Breast Cancer Cell Line Before and After Doxorubicin Treatment
}

\begin{abstract}
Aim: In the treatment of cancer, one of the problems encountered in clinical therapy of tumor cells had developed resistance against chemotherapy patients. The ABC (ATP-binding cassette) protein that helps drugs outside the cell membrane and has shown resistance of tumor cells to these drugs, is one of the most important members of transporter proteins. Besides that drug resistance protein is known to be effective on other intracellular proteins. In this context, the alkylating functionality at developing resistance to the cancer drug has been reported that increased level intracellular glutathione and glutathione S- conjugates have a role in cancer chemoresistance.
\end{abstract}

Method: In this study, the expression of GST isoenzyme family and ABC transporter proteins in drug-treated and untreated breast cancer MCF-7 cell line was examined by the immunocytochemical method.

Results: It was observed that the expression of GSTP1, GSTT1, GSTM1, GSTA1, GSTO1, GSTZ1 and GSTK1 protein in drug-treated breast cancer MCF-7 cell line was higher than that of 
untreated cells, no GSTS1 protein was found. The MRP 2,3,6,7 protein expressions in drugtreated breast cancer MCF-7 cell line was found to be higher than in the untreated cells, no MDR, MRP1 proteins were found. Also, bcl-2, p53, p38, caspase-3 protein expressions in drugtreated breast cancer MCF-7 cell line were found to be higher than in untreated cells.

Conclusion: MRP-2,3,6,7 of the $\mathrm{ABC}$ superfamily have a role in the development of breast cancer, and GST isoenzymes are important in drug resistance.

Keywords: Breast cancer, GST, MDR, MRP, immunocytochemistry.

\section{Giriş}

Kanser, hücrelerin kontrolsüz bir şekilde çoğalması, invazif nitelik kazanması ve metastaz yapması ile kendini gösteren ve halen gelişmiş ülkelerin ölüm istatistiklerinde kalp-damar hastalıklarından sonra ikinci sırada yer alan öldürücü bir hastalıktır ${ }^{1}$ En slk görülen kanser türleri erkeklerde akciğer (\%22), kolorektal (\%12) ve prostat (\%11) iken kadınlarda ise meme (\%26), kolorektal (\%14) ve midedir (\%7)².

Meme kanseri tüm dünyada kadınlarda en çok görülen kanser türlerinin başında gelir. Yapılan bazı araştırmalarla ABD'de kadın kanserlerinin \%29,7'sini (1998) ve Türkiye'deki kadın kanserlerinin \%26'sını (1995) oluşturduğu tespit edilmiştir. İnsidansında artışa rağmen erken tanı yöntemleri ve etkin tedavi yaklaşımlarıyla mortalitesi azalma eğilimindedir³.

Var olan ve günümüzde kansere karşı kemoteröpatik olarak kullanılan antikanser ilaçların çoğu, tümör hücrelerine sitotoksik etki göstererek onların büyüme ve çoğalmalarını önlerler. Ancak kanser tedavisinde kesin bir tedavideki amaç, vücutta tek bir malign hücre kalmaksızın tüm hücrelerin yok edilmesidir. Fakat gelinen son noktada böyle bir tedavi birkaç istisna dışında hala mümkün olmamıştır. Antikanser ilaçlarının tedavideki etkinliğini kısıtlayan önemli faktörlerden biri de, tümör hücrelerinin kemotörapatik ajanlara karşı, bazı kanser türlerinde kendiliğ̈inden, bazılarında ise kemoterapiden sonra geliştirdikleri direnç mekanizmalarıdır4,5. Tümör hücrelerinin gösterdiği bu ilaçlara karşı direnç, ilaçların hücre dışına atılmasını sağlayan membran proteinlerinin ekspresyonunun bir sonucudur ve ilaçların hücre içindeki konsantrasyonlarının düşmesine neden olmaktadır ${ }^{6}$. $\mathrm{Bu}$ membran 
proteinlerinden en önemli üyelerinden biri de ABC (ATP-binding cassette) taşıyıcı proteinleridir. Son yıllarda yapılan çalışmalarda ilaç metabolizmasındaki değişiklikler, açıklanan bu ilaç dirençlilik proteinlerinin yanında diğer hücre içi proteinlerinde etkin olabileceğini göstermiştir. Bu bağlamda, alkilleyici özellikteki kanser ilaçlarına gelişen dirençte, hücre içi glutatyon ve glutatyon S- konjugatlarının seviyelerinin artmasının rolünün olduğu bildirilmiştir ${ }^{1}$. Glutatyon S-transferazlar, endojen ve ekzojen kaynaklı, elektrofilik ve hidrofobik bileşiklerin glutatyon ile konjugasyonunu sağlayarak, genellikle daha kolay atılabilen ve daha az toksik metabolitlere dönüşümünü katalizleyen Faz II. detoksifikasyon enzim ailesidir7.

\section{Gereç ve Yöntem}

Kırıkkale Üniversitesi Merkez Araştırma Hücre Kültürü Laboratuvarlarında bulunan MCF-7 meme kanser hücre hatlarının çoğaltılması ve ilaç uygulaması yapılabilmesi için içeriğinde $89 \mathrm{ml}$ RPMI 1640 (hazır besi yeri), $10 \mathrm{ml}$ serum, $1 \mathrm{ml}$ doksorubisin kullanılarak $100 \mathrm{ml}$ besi yeri hazırlanmıştır. Hazırlanan besi yeri iki ayrı deneme uygulamasında kullanılmıştır. I. denemede 48'lik mikroplakaların her bir kuyucuğuna $200 \mu \mathrm{l}$ besi yeri konulmuş, her birinde 20.000 hücre olacak şekilde ekim yapılmış ve \%5 $\mathrm{CO}_{2}^{\prime}$ li etüvde $37^{\circ} \mathrm{C}$ ' de hücreler tam tabaka olana kadar inkübe edilmiştir. İnkübasyon süresi tamamlandıktan sonra belirlenen doksorubisin dozlarına göre ilk iki uygulama art arda günlerde ve diğer iki uygulama ikişer gün arayla uygulanmıştır. Besi yeri de uygulama süresince 2-3 gün arayla değiştirilmiştir. İlaç uygulama öncesi ve sonrasında inverted mikroskopta dozlara göre hücrelerin canlılığı gözlemlenmiştir. İlaç uygulamaları tamamlandıktan sonra 1/100 dilüsyonda MDR-1 antikoruyla immünositokimyasal olarak boyanmıştır. İkinci denemede 24'lük mikro plakalara ekilen hücrelere aynı doz uygulamaları tekrarlanmış ve uygulamaların sonuçları inverted mikroskopta gözlemlenmiştir.

\section{Materyal (Hücre Kültürü ve Etkin Dozun Belirlenmesi)}

RPMI-1640 besi yeri, 10\%'luk FBS ve doksorubisin içeren ortamlara MCF-7 hücreleri ekilmiş ve inkübasyon süresi tamamlandıktan sonra $0 ; 1,25 ; 2,5 ; 5 \mu \mathrm{M}$ ve ilaç uygulama öncesi ve sonrasında inverted mikroskopta dozlara göre hücrelerin canlılığ gözlemlenmiştir. İlaç seyreltilmeden Doksorubisin (1000mg/20ml) art arda 2 gün ve 
ikişer gün arayla 2 kez daha daha uygulanmıştır. Besi yeri de uygulama süresince 2-3

gün arayla değiştirilmiştir. İlaç uygulama öncesi ve sonrasında inverted mikroskopta dozlara göre hücrelerin canlılığı gözlemlenmiştir. İlaç uygulamaları tamamlandıktan sonra 1/100 dilüsyonda MDR-1 antikoruyla immünositokimyasal olarak boyanmıştır. 2,5 $\mu \mathrm{M}$ 'lı doza kara verilmiştir. Yeniden ekilen MCF-7 hücre hatlarına 2,5 $\mu \mathrm{Ml}$ lk Doksorubisin dozu 2 gün arayla 12 gün boyunca uygulanmış ve her uygulamada besi yeri değiştirilmiştir. Kontrol grubu olarak da ilaç uygulanmamış hücre hatları kullanılmıştır. Tripsinle kaldırılan hücrelere immünsitokimya yöntemiyle MDR, MRP1, MRP-2, MRP-3, MRP-6, MRP-7, GSTA1, GSTM1, GSTT1, GSTS1, GSTZ1, GSTO1, GSTK1, GSTP1, Bcl-2, Caspaz-3, P38, P53 antikorları uygulanmıştır. İmmünsitokimya yapılan kontrol ve ilaç uygulanmış hücre grupları yoğunluklarına göre inverted mikroskopta 20x lik objektifte değerlendirilmiştir.

\section{İmmunositokimyasal Boyama Yöntemi}

Hücre ekimleri yapılmış ve farklı dozlarda ilaç uygulanmış kuyucuklara hücrelerin üstünü kapatacak şekilde \%70'lik alkol (1dk.), daha sonra $1 \mathrm{dk}$. $\mathrm{dH}_{2} \mathrm{O}$ uygulanmıştır. Distile suda 1-2 dakika bekletilen preparatlar endojen peroksidaz aktivitesinin inhibisyonu için 10 dakika $\mathrm{H}_{2} \mathrm{O}_{2}$ blokajında bekletilmiştir. Çeşme suyunda 5 dakika yıkanan preparatlar PBS tampona batırılıp çıarıldıktan sonra antijen retrival solüsyonu içerisinde düdüklü tencerede 3 dakika kaynatılmıştır. Nonspesifik boyanmanın engellenmesi amacıyla protein blocking solüsyonunda 10 dakika bekletilen preparatlara 1 saat süreyle uygun dilüsyon oranlarında hazırlanan antikorlar (GSTP 1/750, GSTM1 1/400, GSTT1 1/350, GSTO1 1/300, GSTK1 1/500, MDR 1/100, MRP1 1/250, MRP2 1/250, MRP 1/250, MRP3 1/250, BXP21 1/100, BXP34 1/150, p53 1/100, p38 1/50, caspase-3 1/100, bcl-2 1/100) uygulanmıştır. Aralarda PBS tamponla 3 kere yıkanmak şartıyla örneklere sırasıyla, 10 dakika sekonder antikor ardından streptavidin-proksidaz kompleksi uygulanmıştır. Tekrar 3 kere PBS tamponla yıkanan preparatlar 5 dakika DAB da tutulduktan sonra 1 dakika distile suda yıkanmıştır. 2 dakika hemotoksilende bekletilen preparatlar yükselen alkol serilerinden 1'er dakika geçirilerek ksilolde 5 dakika bekletilmiştir. Son olarak entellan ile preparatlar kapatılmıştır. İmmunositokimyasal değerlendirmeler ışık mikroskobunda, dokuların boyanma derecelerine göre; (o): negatif boyanma (protein ifadesi yok), (+1): hafif 
şiddette protein ifadesi, $(+2)$ : orta şiddette protein ifadesi, $(+3)$ : şiddetli boyanma ifadesi şeklinde yapılmıştır. Farklı dozlarda uygulama yapılan platedeki kuyucukların her biri inverted mikroskop da değerlendirilerek fotoğrafları çekilmiştir.

\section{Bulgular}

Genel olarak GST izozimlerinin protein ifadeleri ilaç öncesinde ve sonrasında incelendiğinde; GSTP1, GSTT1 GSTM1 GSTK1 GSTO1 GSTZ1 izozimleri ilaç öncesine göre ilaç sonrasında artmıştır. GSTS1 izozimi ise ilaç öncesi ve sonrasında negatiftir (Tablo 1) (Şekil 1).

Tablo 1. MCF-7 meme kanser hücre hattında ilaç öncesi ve sonrasında GST izozimlerinin protein ifadeleri

\begin{tabular}{|c|c|c|c|c|c|c|c|c|}
\hline & GSTA1 & GSTM1 & GSTP1 & GSTT1 & GSTS1 & GSTZ1 & GSTK1 & GSTO1 \\
\hline $\begin{array}{l}\text { MCF-7 } \\
\text { Kontrol }\end{array}$ & $2+$ & - & - & - & - & - & $1+$ & $2+$ \\
\hline $\begin{array}{l}\text { Doksorubusin } \\
\text { uygulanmış } \\
\text { MCF-7 }\end{array}$ & $3^{+}$ & $1+$ & $3^{+}$ & $1+$ & - & $3^{+}$ & $3^{+}$ & $3^{+}$ \\
\hline
\end{tabular}

(o): negatif boyanma (protein ifadesi yok), (+1): hafif şiddette protein ifadesi, (+2): orta şiddette protein ifadesi, $(+3)$ : şiddetli boyanma 
Şekil 1: MCF-7 meme kanser hücre hattında immunositokimyasal yöntemle GST izozimlerinin protein ifadeleri

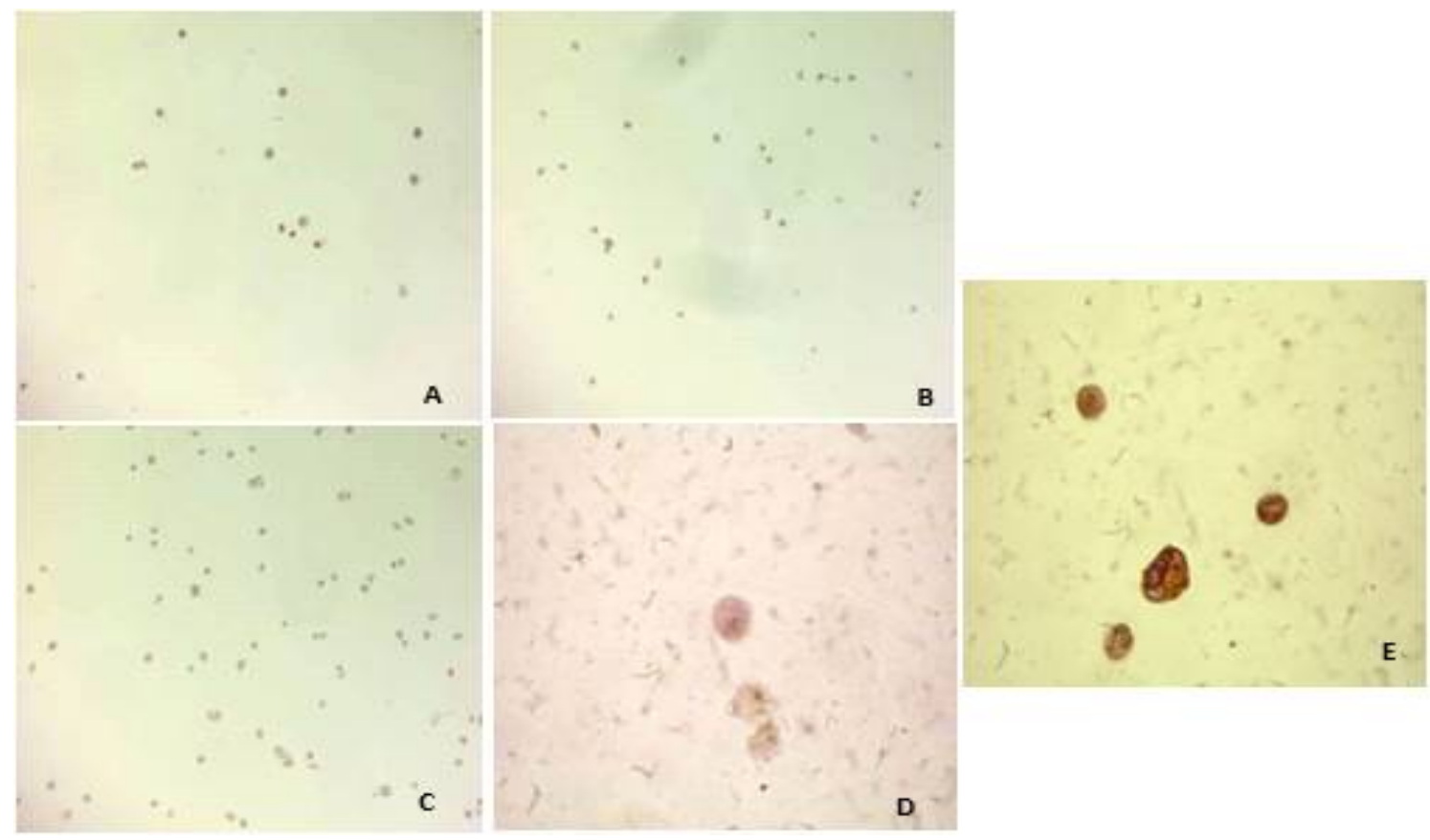

A: MCF-7 meme kanser hücre hattında immunositokimyasal GSTM1 proteini, 100X.

B: MCF-7 meme kanser hücre hattında immunositokimyasal GSTA1 proteini, 100X.

C: MCF-7 meme kanser hücre hattında immunohistokimyasal GSTT1 proteini, 10oX.

D: MCF-7 meme kanser hücre hattında immunositokimyasal GSTP1 proteini, 40oX.

E: MCF-7 meme kanser hücre hattında immunositokimyasal GSTK1 proteini, 40oX.

MDR, MRP 1, 2, 3, 6, 7 izozimlerinin protein ifadeleri ilaç öncesinde ve sonrasında incelendiğinde; MRP 2, 3, 6, 7 ilaç öncesine göre ilaç sonrasında artmıştır. MDR, MRP1 proteinleri ise ilaç öncesi ve sonra MDR, MRP1 proteinleri izlenmemiştir. 
Tablo 2. MCF-7 meme kanser hücre hattında ilaç öncesi ve sonrasında dirençlilik protein ekspresyonları

\begin{tabular}{|c|c|c|c|c|c|c|}
\hline & MDR & MRP1 & $\mathrm{MRP2}$ & $\mathrm{MRP} 3$ & MRP6 & $\mathrm{MRP7}$ \\
\hline MCF-7 Kontrol & - & - & - & - & $1+$ & $2+$ \\
\hline \multicolumn{7}{|l|}{ Doksorubusin } \\
\hline uygulanmış & - & - & $1+$ & $1+$ & $3^{+}$ & $3^{+}$ \\
\hline MCF-7 & & & & & & \\
\hline
\end{tabular}

(o): negatif boyanma (protein ifadesi yok), (+1): hafif şiddette protein ifadesi, $(+2)$ : orta şiddette protein ifadesi, $(+3)$ : şiddetli boyanma

Şekil 2: MCF-7 meme kanser hücre hattında ilaç dirençlilik protein ifadeleri

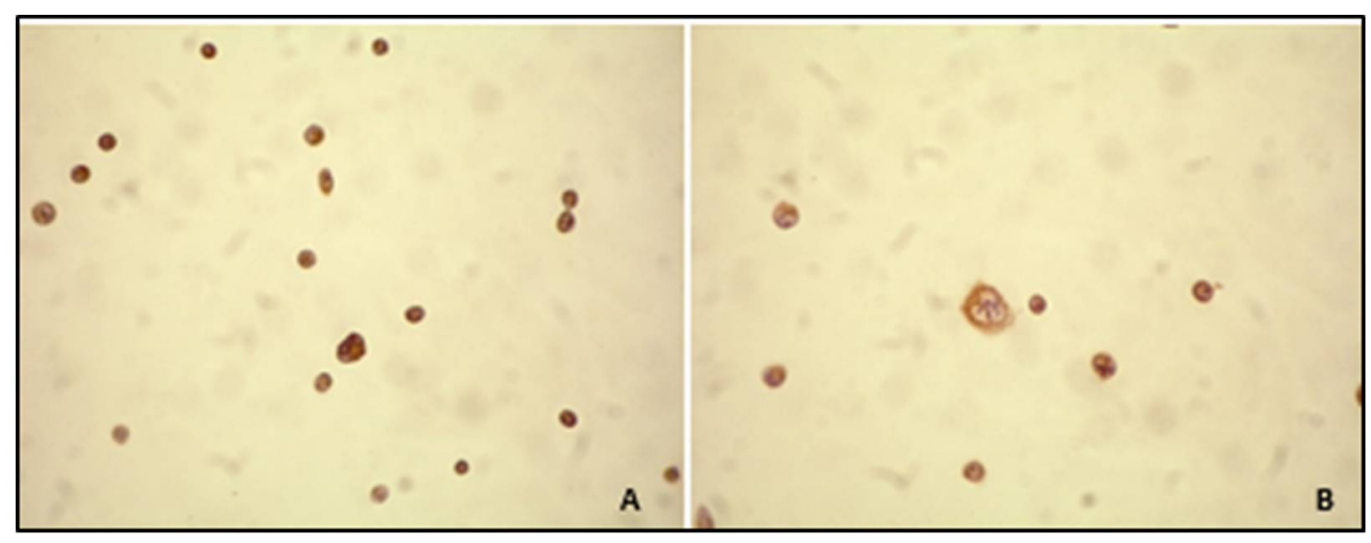

A: MCF-7 meme kanser hücre hattında immunositokimyasal MPR6 proteini, 10oX.

B: MCF-7 meme kanser hücre hattında immunositokimyasal MRP2 proteini, 100X.

Apoptotik protein ifadeleri ilaç öncesinde sonrasında incelendiğinde; p53, caspase-3, p38, bcl-2 izozimleri ilaç öncesine göre ilaç sonrasında artmıştır (Tablo 3) (Şekil 3). 
Tablo 3. MCF-7 meme kanser hücre hattında ilaç öncesi ve sonrasında apoptoz proteinlerinin ekspresyonları

\begin{tabular}{lcccc}
\hline & Bcl-2 & Caspase-3 & P38 & P53 \\
\hline MCF-7 Kontrol & $1+$ & $1+$ & - & - \\
Doksorubusin & $3+$ & $2+$ & $2+$ & $2+$ \\
uygulanmiş MCF-7 & & & & \\
\hline
\end{tabular}

(o): negatif boyanma (protein ifadesi yok), (+1): hafif şiddette protein ifadesi, (+2): orta şiddette protein ifadesi, $(+3)$ : şiddetli boyanma

Şekil 3: MCF-7 meme kanser hücre hattında immunohistokimyasal Apoptotik Protein Ífadeleri

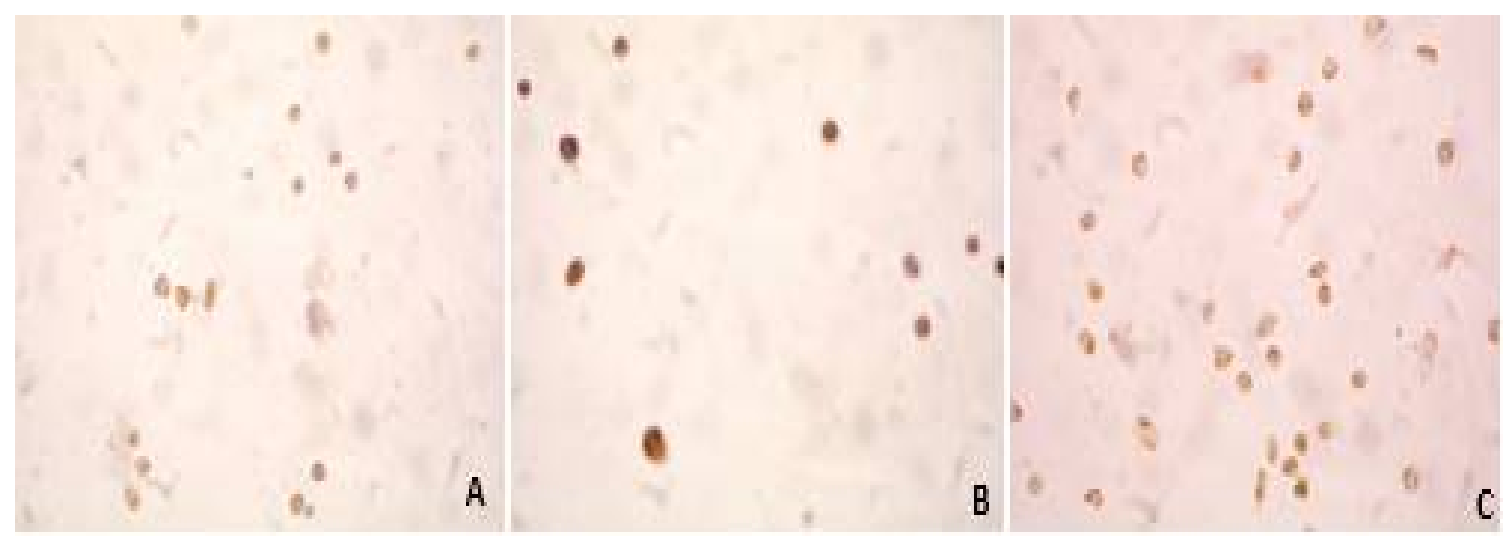

A: MCF-7 meme kanser hücre hattında immunohistokimyasal caspase-3 proteini, 100X.

B: MCF-7 meme kanser hücre hattında immunohistokimyasal p38 proteini, 100X.

C: MCF-7 meme kanser hücre hattında immunositokimyasal bcl-2 proteini, $100 \mathrm{X}$.

\section{Tartışma}

Meme kanseri kadınlar arasında görülen en yaygın kanser türüdür8. Meme kanseri tedavisinde kullanılan yöntemler arasında cerrahi, radyoterapi, hormonoterapi ve en yaygın olarak kullanılan yöntem sistemik kemoterapidir. Kanser tedavisinde başarıya 
ulaşmayı engelleyen en önemli sorun uygulanan kemoterapiye karşı tümör hücrelerinin kazandığı dirençtir. Bunun sebebi ise birden fazla antineoplastik ilaç uygulanılmasıdır. Kemoterapiye karşı geliştirilen dirençlilik pek çok antikanser ilacın tümör hücreleri üzerinde beklenen etkisini gösterememesine ve hastalığın ilerlemesine neden olmaktadır.

Çoklu ilaç dirençliliği birden fazla ve birbirinden farklı ilaca direnç gelişimidir`. Hücre içi yetersiz ilaç konsantrasyonunun nedeni membran geçirgenliğinin bozulmasıdır ve tümör hücrelerinin gösterdiği bu ilaçlara karşı direnç, ilaçların hücre dışına atılmasını sağlayan membran proteinlerinin ekspresyonunun bir sonucudur ve ilaçların hücre içindeki konsantrasyonlarının düşmesine neden olmaktadır5. $\mathrm{Bu}$ membran proteinlerinden en önemli üyelerinden biride ABC (ATP-binding cassette) taşıyıcı proteinleridir. P-gp'nin normal dokularda da eksprese olması bu proteine, toksik maddelerin hücre içine girişine engel olmak ve hücre içinde oluşan zararlı bazı ksenobiyotiklerin hücre dışına tekrar pompalanmasını sağlamak gibi önemli fizyolojik roller yüklemektedir. P-gp'nin normal hücre metabolizması için gerekli ve koruyucu bir protein olduğu ve bu açıdan bakıldığında karsinogenez sürecinde rol oynayabileceği öne sürülmektedirio.

Son yıllarda yapılan çalışmalarda ilaç metabolizmasındaki değişiklikler, açıklanan bu ilaç dirençlilik proteinlerinin yanında diğer hücre içi proteinlerinde etkin olabileceğini göstermiştir. Bu bağlamda, alkilleyici özellikteki kanser ilaçlarına gelişen dirençte, hücre içi glutatyon ve glutatyon S- konjugatlarının seviyelerinin artmasının rolünün olduğu bildirilmiştir. GST’ler substratları olan, 4-hidroksil-2-nonenal, kolesterol-5,6oksit, adenin propenal, 9-hidroperoksilinoleik asit, dopaminokrom, aminokrom gibi endojen moleküllerin; bütadien, akrolein, aflatoksin B1-8,9-epoksit, hekzaklorobütadien, trikloroetilen, stiren oksit, metilen klorid, etilenoksit, nitrokinolin oksit gibi çevresel karsinojenlerin; lindan, atrazin, DDT gibi pestisitlerin ksenobiyotik metabolizmasında detoksifikasyonunu sağlarken, başta cis-platin gibi, platin bazlı kanser ilaçları olmak üzere, klorambusil, siklosofamid, tiyotepe, fosfomisin, etakrinik asit, nitrogliserin, adriamisin, asetaminofen gibi ilaçlarında aktivitelerini inhibe ederek hücrede bu ilaçlara karşı direncin gelişmesine neden olurlar'11,12. 
Son zamanlarda ilaç rezistansı mekanizmaları üzerindeki çalışmalar kanser hücrelerinin kemo rezistansında çeşitli faktörlerin rol oynadığını göstermiştir. Bunlar arasında glutatyon S-transferazlar (GST) önemli faktörlerden birisidir ${ }^{13,14}$. GST’ler, faz II enzimlerinden olup elektrofilik özellikteki toksik maddelerin inaktivasyonunu sağlayan glutatyon konjugasyonunu katalizleyen enzimlerdir. Özellikle platinyum bileşiklerinin detoksifikasyonuna GSTP1'nin doğrudan katılmakta olduğu ve platinyum bileşiklerine karsı gelişen gerek intrinsik ve gerekse kazanılmış rezistansta önemli rol oynadığı ileri sürülmektedirr5,16.

Fengxi-Su ve arkadaşlarını (2003) yılında meme kanseri tümörlerinde de, GSTP geninin varlığının bu tümörlerin kemoterapiye karşı direnç oluşturduğunu göstermektedir ${ }^{17}$.

Jingxiang ve arkadaşlarını (2003) yılında yapmış olduğu meme kanserli hastaların tümörlü dokularında GSTP1 izoziminin daha fazla agresif olduğunu ve kötü prognoza sebep olduğunu bildirmişlerdir ${ }^{18}$.

Gilbert ve arkadaşlarının (1993) yılında yaptıkları çalışmada GSTP1 izoziminin meme kanserli hastalarda hormon reseptörünün belirleyicisi olduğunu ve artan GSTP1 ekspresyonunun meme kanserinin sağ kalımında önemli bir belirleyicisi olduğunu bildirmiştir ${ }^{19}$.

Garcia-Closas ve arkadaşları (1999) yılında meme kanserli hastalarda yaptıkları çalışmada GSTM1 ve GSTT1 homozigot gen delesyonun meme kanseri riskini önemli ölçüde arttırdığını ileri sürmüşlerdir²0.

$\mathrm{Bu}$ çalışmada ilaç uygulanmış meme kanserli MCF-7 hücre hattında GSTP1, GSTT1, GSTM1, GSTA1, GSTO1, GSTZ1 ve GSTK1 protein ifadelerinin ilaç uygulanmamış hücrelere oranla daha yüksek olduğu görülmüş, GSTS1 proteini bulunamamıştır. İlaç uygulanmış meme kanserli MCF-7 hücre hattında MRP 2,3,6,7 protein ifadelerinin ilaç uygulanmamış hücrelere oranla daha fazla olduğu görülmüştür, MDR, MRP1 proteinleri izlenmemiştir. Ayrıca ilaç uygulanmış meme kanserli MCF-7 hücre hattında Bcl-2, p53, p38, caspase-3 protein ifadelerinin ilaç uygulanmamış hücrelere oranla daha fazla olduğu görülmüştür. 
Nakapoulou ve arkadaşları (2001) meme kanserli hücrelerde yaptıkları çalışmada caspase-3 proteininin aşırı ekspresyonunun apoptotik yolakta p53 ve Bcl-2 proteinini etkilediği ve caspase-3 proteininin aşırı ekspresyonunun meme kanserli hastaların sağ kalımları üzerinde olumsuz etki yaptığı belirlenmiştir ${ }^{21}$.

Gorczyca ve arkadaşları (1995) 59 meme kanserli hastalarda immünohistokimyasal yöntemle p53 ve Bcl-2 proteininin ekspresyonunu incelemiş ve meme kanserli hastaların çoğunda negatif korelasyon gösterdiği ve ekspresyonun tümör poliferasyonu ile ilintili olduğu sonucuna varmıştır ${ }^{22}$.

Pilco-Ferreto ve arkadaşlarının (2016) yaptıkları çalışmada DOX uygulanan MCF-7 hücre hatlarında anti-apoptotik Bcl-2 protein ifadesinin azaldığı da literatürde rapor edilmektedir ${ }^{23}$.

Nooter ve arkadaşları (1997) yılında meme kanserli dokularda yaptıkları çalışmalarında MRP'yi monoklonal antikorlarla ve immünohistokimyasal yöntemle belirleme çalışmışlardır. Sonuç olarak MRP’nin kanserli dokularda aşırı eksprese olduğunu bulmuşlar ve MRP'nin kanserli dokularda önemli bir kemoterapötik ajan olduğun u belirlemişlerdir ${ }^{24}$.

Taniguchi ve arkadaşlarının (1996) yaptıkları çalışmada insanlarda cisplatin dirençli baş ve boyun kanserli hücre hatlarında MRP2’in aşırı eksprese olduğunu bildirmiştir²5.

Kool ve arkadaşları (1997) ise MRP1'in zıttına MRP2'in ilaca dirençli insan kanser hücre hatlarında cisplatin direncine korele olduğunu bildirmişlerdir ${ }^{26}$.

Ishikawa ve arkadaşları (1993) ise cisplatin dirençli HL-P/R-CP hücre hatlarında ilacın GS-X pompaları tarafından MRPı kanalı tarafından dışarı atıldığını söylemektedir. MRP’lerincisplatin direncindeki rolü hala tartışmalı olarak kalmaktadır²7.

Faneyte ve arkadaşları (2004) yılında meme kanserli hastalarda immunohistokimyasal yöntemle yaptıkları çalışmada MRP1, MRP2 ve MRP3’ün ekspresyonlarını belirlemeye çalışmışlardır. MRP1, MRP2 ve MRP3’ün meme kanserli hücre hatlarında tümör oluşumunda birbirleriyle ilişkili olmadığını ve bunun immunohistokimyasal çalışmayla yöntemiyle başarısız olduğunu ve bu proteinlerin meme kanserinde ilaç dirençliliğiyle bağlantılı olmadıklarını ileri sürmüşlerdir²8. 
Leah ve arkadaşlarının (2001) yılında akciğer kanserli hastalarda yapmış oldukları çalışmada MRP1, MRP2 ve MRP3’ü poliklonal antikorlarla belirlemeye çalışmış ve MRP1 ve MRP3'ün doksorubisin dirençli akciğer kanserli hücre hatlarında ilaç dirençlilik proteini olarak multi fonksiyonel bir göreve sahip olduklarını ve ayrıca MRP3'ün KHDAK hücrelerinde içsel direnç sağlamaya katkıda bulunduğunu bildirmişlerdir29.

Larkin ve arkadaşları (2004) yılında meme kanserli MCF hücre hatlarında MRP1 ve MDR1 proteinlerinin immünohistokimyasal yöntemle klinik parametrelerle korele olduğunu,MDR1'in evre 3 ve aynı zamanda MRP1 ile yüksek derecede ilişkili olduğunu ancak, MRP1'in evre 1 ve evre 2'de belirleyici prognostik bir protein olduğunu,MDR1'in hastalıksız ve genel sağ kalımla ilişkisi olmadığını bulmuşlardırº.

Filipits ve arkadaşlarının (1996) yaptıkları meme kanserli hastalarda MRP1 ve MDR1 proteinleri arasında hiçbir korelasyon olmadığını ancak her iki proteininde meme kanserinde protein ifadesinin olduğunu ve bunların ilaç dirençliliğinde rolü olduğunu bulmuşlardır ${ }^{31}$.

Keith ve arkadaşları (1990) yılında meme kanserli dokularda yaptıkları çalışmalarda GST izoenzimlerinden olan GSTP ile MDR-1 geninin korele bir şekilde arttığını belirlemiş ve sonuç olarak kemoterapi alan meme kanserli hastaların MDR-1 geninin ifadesinin önemli olduğunu vurgulamıştır ${ }^{2}$.

Terrier ve arkadaşlarının (1990) normal insan dokularında yapmış oldukları çalışmada GSTP1 ve MDR1'in normal dokular arasındaki dağılımı arasında bir benzerlik olduğunu ve her ikisininde tümörlü ve normal dokularda sitotoksik ilaçlara karşı direnç sağladığı immünohistokimyasal yöntemle belirlemeye çalışmışlardır33.

Juliano ve arkadaşları (1976), Ueda ve arkadaşları, (1987); kanser hücrelerinde, çoklu ilaç direncinin en önemli mekanizması P-glikoprotein (Pgp) olarak bilinen enerji bağımlı ilaç atım pompalarının fazla ekspresyonunun olduğunu bildirmişlerdir ${ }^{34,35}$.

Sun ve arkadaşları (2004) yaptıkları çalışma da P-gp'nin ilacın absorbsiyonu, dağılımı, atılımı gibi işlemlerde önemli rolü olduğunu göstermişlerdir³6. 
Cole ve arkadaşları (1992) yaptıkları bir çalışmada glutatyon konjugatlarının taşınmasında, çoklu ilaç dirençli protein olarak adlandırılan (MRP) ve ilaca dirençli MDR substratlarının aracılık ettiklerini bildirmişlerdir ${ }^{37}$.

\section{Sonuç}

Özetle söylenecek olursa; GST izozimlerinin protein ifadelerinin farklılıkları incelenmiş ve bu izozimlerin kanser oluşumunda ksenobiyotik ve ilaç metabolizmasında görev alan çoklu ilaç dirençlilik proteinleriyle olan ilişkisi aydınlatılmaya çalışılmıştır. İmmunositokimyasal açıdan incelendiğinde literatür verilerine uygun olarak çalışmada ilaç almış ve almamış MCF-7 meme kanser hücre hattında GSTP1, GSTT1, GSTA1, GSTO1, GSTT1, GSTK1 ve çoklu ilaç dirençlilik proteini olan MRP 2,3,6,7 nin rolleri olduğu bulunmuştur. Antikanser ilaçların inaktivasyonunda birinci derecede sorumlu enzim olduğu bilinen glutatyon S-transferazların kemoterapötik bileşiklere direnç gelişmiş pek çok kanser türünde fazla salgılandığı bilinmektedir. Enzimin GSH konjugasyonu ile kemoterapötik bileşiklerin metabolizmasını artırarak, etki yöresinde ilacın etkili konsantrasyona ulaşılamaması sonucu, ilaca direnç gelişimine sebep olduğu düşünülmektedir. Tümör hücrelerinde kanser ilaçlarına karşı oluşan dirençten sorumlu olduğu bilinen ABCC (MRP 1-9) süper ailesidir. Bu çalışmada, ABCC süper ailesinden MRP-2,3,6,7'nin meme kanseri oluşumunda rolü olduğunu ve GST'lerin ilaç dirençliliğine neden olduğunu söylenebilir.

\section{KAYNAKLAR}

1. Tozkoparan B, Peri Aytaç S. Kanser kemoterapisinde terapötik hedef olarak glutatyon S-transferazlar. Hacettepe Üniversitesi, Eczacılık Fakültesi Dergisi. 2007;7(2):139-164.

2. Dünyada Kanser İstatistikleri. Türk Kanser Araştırma ve Savaş Kurumu (TKASKD).http://turkkanser.org.tr. Yayınlanma tarihi 1995. Erişim tarihi 20.09.2019.

3. Onur H. Tzbbi Onkoloji Kitabı. Ankara Üniversitesi Tıp Fakültesi: Antıp Yayınları; 2005. 
4. Gate L, Tew KD. Glutathione S-transferases as emerging targets, Expert Opin Ther. Targets. 2001;5(4):477-489.

5. Szakács G, Paterson, JK, Ludwig JA, Booth-Genthe C, Gottesman MM. Targeting multidrug resistance in cancer. Nat Rev Drug Discov. 2006;5(3):219-34.

6. Stavrovskaya AA, Stromskaya TP. Transport proteins of the ABC familya and multidrug resistance of tumor cells. Biochemistry (Mosc). 2008;73(5):592-604.

7. Jemal A, Siegel R, Ward E, Hao Y, Xu J, Thun MJ. Cancer statistics. CA Cancer J Clin 2009;59(4):225-249. doi: 10.3322/caac.20006.

8. Tuncer M. Significance of cancer in Turkey, the burden of disease and cancer control policies. Cancer Control in Turkey, Ankara, Onur Press, Health Ministry Publication. 2008:74;5-9.

9. Marie JP, Legrand O. Drug resistance in acute leukaemia and reversion. Turk $J$ Med Sci. 2003;33:271-279.

10. Turgut S, Yaren A, Kursunluoğlu R, Turgut G. MDR1 C3435T polymorphism in patients with breast cancer. Arch Med Res. 2007:38;539-544.

11. Eaton DL, Bammler TK. Concise Review of glutathione s-transferase and their significance to toxicology. Toxicological Sciences. 1999;49:156-164.

12. Oguztuzun S, Abu-Hijleh A, Coban T, et al. GST isoenzymes in matched normal and neoplastic breast tissue. Neoplasma. 2011;58(4):304-310.

13. Buller Al, Clapper M, Smith T, Tew KD Glutathione S-trasnferase in nitrogen mustard-resistance and-sensitive. Molecular Pharmacology. 1987;31(6):575-578.

14. Oguri T, Fujimara Y, Katoh O, et al. Glutathione S-transferase gene expression and platinum drug exposure in human lung cancer. Cancer Letters. 2000;156:9399.

15. Ban N, Takahashi Y, Takayama T, et al. Transfection of glutathione S-transferase (GST)-pi anti sense complementary DNA increase sthesensitivity of a colon cancer cell line to adriamycin, cisplatin, melphalanandetoposide. Cancer Res. 1996;56:3577-3582. 
16. Goto S, Ieda T, Cho S, Oka M, Kohno S, Kondo T. Over expression of glutathione S-transferase pi enhances the adduct formation of cisplatin with glutathione in human cancer cells. Free RadicRes. 1999;31:549-558.

17. Fengxi S, Xiaogu H, Weijuan J, Chang G, Erwei S, Peter H. Glutathione S Transferase $\pi$ indicates chemotherapy resistance in breast cancer. Journal of Surgical Research. 2003;113:102-108.

18. Jingxiang H, Puay-Hoon T, Jayabaskar T, Boon-Huat B. Prognostic significance of glutathione s-transferase-pi in invasive breast cancer. Mod Pathol 2003;16(6):558-565.

19. Gilbert L, Elwood L, Merino M, et al. A pilot study of pi-class glutathione Stransferase expression in breastcancer: correlation with estrogen receptor expression and prognosis in node-negative breast cancer. JCO. 1993;11(1):49-58.

20. García-Closas M, Kelsey KT, Hankinson SE, et al. Glutathione S-Transferase Mu and Theta Polymorphisms and Breast Cancer Susceptibility. JNCI J Natl Cancer Inst. 1999;91(22):1960-1964.

21. Nakopoulou L, Alexandrou P, Stefanaki K, Panayotopoulou E, Lazaris AC, Davaris PS. Immunohistochemical expression of caspase-3 as an adverse indicator of the clinical outcome in human breast cancer. Patobiology. 2001;69:266-273.

22. Gorczyca W, Markiewski M, Kram A, Tuziak T, Domagala W. Immunohistochemic alanalysis of BCL-2 and p53 expression in breast carcinomas: their correlation with Ki-67 growth fraction. Virchows Archiv. 1995;426(3):229-233.

23. Pilco-Ferreto N, Calaf GM. Influence of doxorubicin on apoptosis and oxidative stress in breast cancer cell lines. Int $J$ Oncol. 2016;49(2):753-62

24. Nooter K, Brutel G, Riviere de la M, et al. The prognostic significance of expression of the multidrug resistance-associated protein (MRP) in primary breast cancer. Br J Cancer. 1997;76(4):486-493. 
25. Taniguchi K, Wada M, Kohno K, et al. A human canalicular multi specific organic anion transporter (cmoat) gene is overexpressed in cisplatin-resistant human cancer cell lines with decreased drug accumulation. Cancer Res. 1996;56:4124-9.

26. Kool M, de Haas M, Scheffer GL, et al. Analysis of Expression of cMOAT (MRP2), $\mathrm{MRP}_{3}, \mathrm{MRP}_{4}$ and $\mathrm{MRP}_{5}$ homologues of the multidrug resistance-associated protein gene (MRP1), in human cancer cell lines. Cancer Res. 1997;57:3537-47.

27. Ishikawa T, Ali Osman F. Glutathione-associatedcis-diammine dichloro platinum (II) metabolism and ATP-dependent efflux from leukemia cells. Molecular characterization of glutathione-platinum complex and its biological significance. The Journal of Biological Chemistry. 1993;268:20116-20125.

28. Faneyte IF, Kristel PM, van de Vijver MJ. Multidrug resistance associated genes MRP1, MRP2 and MRP3 in primary and anthracycline exposed breast cancer. Anticancer Research. 2004;24:2931-2940.

29. Leah C, Young B, Campling G, et al. Multi drug resistance proteins MRP3, MRP1 and MRP2 in lung cancer correlation of protein levels with drug response and messenger RNA levels. Clin Cancer Res. 2001;7:1798.

30. Larkin A, O'Driscoll L, Kennedy S, et al. Investigation Of MRP-1 Protein And MDR-1 P-Glycoprotein expression in invasive breast cancer: a prognostıc study. J. Cancer. 2004;112:286-294.

31. Filipits M, Suchomel RW, Dekan G, et al. MRP and MDR1 Gene Expression in Primary Breast Carcinomas. Clin Cancer Res. 1996;2:1231-1237.

32. Keith WN, Stallard S, Brown R. Expression of mdr1 and gst-pi in human breast tumours: comparisonto invitro chemosensitivity. Br J Cancer. 1990;61(5):712716.

33. Terrier P, Townsend AJ, Coindre JM, Triche TJ, Cowan KH. An Immunohistochemical study of pi class glutathione s-transferase expression in normal human tissue. American Journal of Pathology. 1990;137:4. 
34. Juliano RL, Ling V. A surface glycoprotein modulation drug permeability in Chinese hamster ovary cell mutants. Biochim. Biophys. Acta. 1976;455(1):152162.

35. Ueda K, Cardarelli C, Gottesman MM, Pastan I. Expression of and full-length c DNA fort he human MDR1 gene confers resistance tocolchicino, doxorubicin and vinblastine. Proc. Natl. Acad. Sci. USA. 1987;84:3004-3008.

36. Sun JH, Cheng ZG, Wang G, Hao SJ, Zou XHMJ. Multidrug resistance Pglycoprotein: crucial significance in drug disposition and interaction. Med. Sci. Monit. 2004;10:5-14.

37. Cole SPC, Bhardwaj G, Gerlach JH, et al. Over expression of a transporter gene in a multi drug-resistant human lung cancer cell line. Science. 1992;258:1650-1654 